Canadian

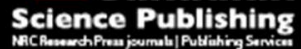

Canadian Journal of Physiology and Pharmacology Revue canadienne de physiologie et pharmacologie

\title{
Tetrahydroxystilbene glucoside inhibits a-synuclein aggregation and apoptosis in A53T a-synuclein-transfected cells exposed to MPP+
}

\begin{tabular}{|r|l|}
\hline Journal: & Canadian Journal of Physiology and Pharmacology \\
\hline Manuscript ID & cjpp-2016-0209.R1 \\
\hline Danuscript Type: & Article \\
\hline Complete List of Authors: & $\begin{array}{l}\text { Zhang, Ruyi; Xuanwu Hospital of Capital Medical University; Beijing } \\
\text { Geriatric Medical Research Center; Beijing Institute for Brain Disorders; } \\
\text { Beijing Engineering Research Center for Nerve System Drugs } \\
\text { Sun, Fangling; Xuanwu Hospital of Capital Medical University, Department } \\
\text { of Pharmacology; Xuanwu Hospital of Capital Medical University, } \\
\text { Experimental Animal Laboratory } \\
\text { Zhang, Lan; Xuanwu Hospital of Capital Medical University } \\
\text { Sun, Xuejing; Xuanwu Hospital of Capital Medical University } \\
\text { Li, Lin; Xuanwu Hospital of Capital Medical University }\end{array}$ \\
\hline Keyword: & $\begin{array}{l}\text { Tetrahydroxystilbene glucoside, MPP<sup>+</sup>, Parkinson's disease, } \\
\text { a-synuclein, A53T a-synuclein-transfected cell }\end{array}$ \\
\hline &
\end{tabular}

\section{SCHOLARONE}

Manuscripts 
Tetrahydroxystilbene glucoside inhibits $\alpha$-synuclein aggregation and apoptosis in A53T $\alpha$-synuclein-transfected cells exposed to $\mathrm{MPP}^{+}$

Zhang, Ruyi ${ }^{\text {a, }}{ }^{\text {; }}$ Sun, Fangling ${ }^{\text {a, }}{ }^{1,2}$; Zhang, Lan ${ }^{1}$; Sun, Xuejing ${ }^{3}$; Li Lin ${ }^{1 *}$

${ }^{1}$ Department of Pharmacology, Xuanwu Hospital of Capital Medical University;

Beijing Geriatric Medical Research Center; Beijing Institute for Brain Disorders;

Beijing Engineering Research Center for Nerve System Drugs; Key Laboratory for Neurodegenerative Diseases of Ministry of Education, Beijing 100053, China

${ }^{2}$ Experimental Animal Laboratory, Xuanwu Hospital of Capital Medical University, Beijing 100053, China

${ }^{3}$ Department of Hematology, Xuanwu Hospital of Capital Medical University, Beijing 100053, China

${ }^{\mathrm{a}}$ The first two authors contributed equally to this work.

*Corresponding author: $\mathrm{Lin} \mathrm{Li}$

Department of Pharmacology, Xuanwu Hospital of Capital Medical University, 45 Chang-chun Street, Beijing 100053, China.

Tel.: +86-10-83198886;

Fax: +86-10-83198855;

E-mail: 1ilin@xwh.ccmu.edu.cn 


\section{ABSTRACT}

Increasing evidence has solidified the involvement of $\alpha$-synuclein ( $\alpha$-Syn) and neurotoxins in the pathogenesis of Parkinson's disease (PD), suggesting a combination of genetic and environmental influences. 2,3,5,4'-Tetrahydroxystilbene -2-O- $\beta$-D-glucoside (TSG) is one of the main active components extracted from Polygonum multiflorum. The purpose of the present study was to investigate the effects of TSG on $\alpha$-Syn aggregation, mitochondrial dysfunction, oxidative stress and apoptosis in vitro. A53T mutant $\alpha$-synuclein-transfected cells (A53T AS cells) plus $\mathrm{MPP}^{+}$exposure were used as a complex cell model of PD. The expression of proteins was determined by western blotting assay. Flow cytometry was utilized to measure mitochondrial membrane potential and apoptosis. The results showed that $\mathrm{MPP}^{+}$ exposure for $24 \mathrm{~h}$ induced more severe damage in A53T AS cells than in vector control cells. Pretreatment of TSG for $24 \mathrm{~h}$ significantly increased the cell viability; decreased lactate dehydrogenase leakage; inhibited $\alpha$-Syn over-expression and aggregation; elevated mitochondrial membrane potential; decreased reactive oxygen species, Bax/Bcl-2 ratio and caspase-3 activity; and inhibited apoptosis in A53T AS cells exposed to $\mathrm{MPP}^{+}$. These results suggest that TSG may be an attractive candidate for PD therapy.

Keywords: Tetrahydroxystilbene glucoside; $\mathrm{MPP}^{+} ; \quad \alpha$-synuclein; A53T $\alpha$-synuclein-transfected cell; Parkinson's disease 


\section{Introduction}

Parkinson's disease (PD) is pathologically characterized by the selective loss of dopaminergic neurons and the presence of Lewy bodies in the substantia nigra. Although the aetiology of PD has not yet been elucidated, increasing evidence supports the 'multi-hit' hypothesis, encompassing both environmental and genetic factors, such as insecticide exposure and $\alpha$-synuclein mutations, respectively. Studies investigating gene-environment interactions therefore can provide a superior understanding of this condition (Johnson and Bobrovskaya 2015). $\alpha$-Synuclein ( $\alpha$-Syn) is the first gene mutations/multiplications unambiguously linked to PD (Ozansoy and Basak 2013). Patients carrying the A53T $\alpha$-Syn mutation have a relatively early onset age and severe Parkinsonism with a frequent dementia (Spira et al. 2001). Mitochondrial dysfunction also plays an important role in the pathogenesis of PD (Moon and Paek 2015). The 1-methyl-4-phenyl-pyridinium ion $\left(\mathrm{MPP}^{+}\right)$, a powerful inhibitor of mitochondrial complex I, causes abnormal energy metabolism and increases the production of reactive oxygen species (ROS), ultimately leading to cell death via mitochondrial impairment (Horowitz and Greenamyre 2010). In vitro studies have shown that $\mathrm{MPP}^{+}$increases $\alpha$-Syn expression (Gomez-Santos et al. 2002; $\mathrm{Xu}$ et al. 2007) and the over-expression of mutant human $\alpha$-Syn aggravates $\mathrm{MPP}^{+}$-induced neurotoxicity (Qian et al. 2008).

Polygonum multiflorum Thunb, a traditional medicine, has been widely used in China as an anti-aging agent since ancient times. 2,3,5,4'-Tetrahydroxystilbene2-O- $\beta$-D-glucoside (TSG) (Fig. 1) is one of the main active components extracted 
from the root of Polygonum multiflorum. Our previous studies found that the oral administration of TSG enhanced learning-memory ability and protected synaptic ultrastructure in the hippocampus of aged rats (Wang et al. 2007). TSG also improved learning-memory impairment, decreased the content of $\beta$-amyloid $(\mathrm{A} \beta)$, and inhibited the over-expression and aggregation of $\alpha$-Syn in the hippocampus of the APPV717I transgenic mouse model of Alzheimer's disease (AD) (Zhang et al. 2013). Our in vitro study found that TSG inhibited the expression and aggregation of $\alpha$-synuclein via up-regulating ubiquitin-proteasome system in $\alpha$-synuclein-transfected PC12 cells (TSG)( Liu et al. 2012). Because $\alpha$-Syn aggregation is a common factor in the pathogenesis of several neurodegenerative diseases including $\mathrm{AD}, \mathrm{PD}$ and dementia with Lewy body (DLB), our previous discoveries about TSG evoked us to hypothesize that TSG might have the potential to treat PD and DLB, in addition to AD.

To verify our hypothesis, the present study investigated the effects of TSG on $\alpha$-Syn aggregation, mitochondrial dysfunction, oxidative stress, apoptosis and related factors in A53T mutant $\alpha$-synuclein-transfected cells (A53T AS cells) exposed to $\mathrm{MPP}^{+}$. We used A53T AS cells plus $\mathrm{MPP}^{+}$exposure because we believed that this complex model might exhibit more significant pathological changes that would better simulate the genetic and environmental influences for PD. The results of the present study showed that A53T AS cells were more vulnerable to $\mathrm{MPP}^{+}$neurotoxicity than the vector control cells. TSG protected A53T AS cells against MPP ${ }^{+}$-induced cell damage, and the underlying mechanisms of TSG were inhibiting $\alpha$-Syn 
over-expression and aggregation, enhancing mitochondria function, reducing ROS level, and inhibiting apoptosis via reductions in the $\mathrm{Bax} / \mathrm{Bcl}-2$ ratio and caspase-3 activity. These results suggest that TSG may be beneficial for PD therapy.

\section{Materials and Methods}

\section{Reagents}

2,3,5,4'-Tetrahydroxystilbene-2-O- $\beta$-D-glucoside (TSG), purity $>98 \%$, was purchased from National Institute for Food and Drug Control (Beijing, China). MPP iodide, 3-[4,5-dimethylthiazol-2-yl]-2,5-diphenyl-tetrazolium bromide (MTT), sodium dodecyl sulphate (SDS), phenylmethanesulphonyl fluoride (PMSF), dimethyl sulphoxide (DMSO), 2',7'-dichlorofluorescin diacetate (DCFH-DA), rhodamine 123, and $\mathrm{N}$-acetyl-Asp-Glu-Val-Asp- $\rho$-nitroanilide (Ac-DEVD- $\rho \mathrm{NA}$ ) were obtained from Sigma-Aldrich (St. Louis, MO, USA). The antibody against $\alpha$-Syn was from Abcam (UK), antibodies against Bax, $\beta$-actin and horseradish peroxidase-conjugated goat anti-mouse IgG were purchased from Santa Cruz Biotechnology, Inc. (USA), and antibodies against Bcl-2 and Alexa Fluor 488-conjugated goat anti-mouse IgG were from Beyotime Biotechnology (Shanghai, China). SuperSignal ${ }^{\mathrm{TM}}$ West Pico Chemiluminescent Substrate was purchased from Thermo Scientific (MA, USA). Fetal bovine serum (FBS), Dulbecco's modified Eagle medium (DMEM), G418 and trypsin were purchased from Gibco Invitrogen (Carlsbad, CA, USA). The bicinchoninic acid (BCA) protein quantitative analysis kit was from Applygen Technologies, Inc. (Beijing, China).

\section{Cell culture and treatment}


A53T mutant human $\alpha$-synuclein-transfected neuroblastoma SH-SY5Y cells (A53T AS cells) and the vector control cells (empty vector-transfected SH-SY5Y cells) were a gift from Xiao-liang Wang (Institute of Materia Medica, Chinese Academy of Medical Sciences). A53T AS cells and the vector control cells were cultured in DMEM supplemented with $10 \%(\mathrm{v} / \mathrm{v}) \mathrm{FBS}$, and kept at $37^{\circ} \mathrm{C}$ in a humidified atmosphere of $5 \% \mathrm{CO}_{2}$ and $95 \%$ air. G418 $(0.3 \mathrm{~g} / \mathrm{L})$ was added to sustain the features.

Serial dilutions of TSG in DMEM were added to cells, at final concentrations ranging from 3.125 to $50 \mu \mathrm{M}$, and incubated with cells for $24 \mathrm{~h}$. The media was then removed and cells were washed twice with phosphate buffered saline (PBS) solution. The cells were then cultured in the media containing $\mathrm{MPP}^{+}$for $24 \mathrm{~h}$.

\section{Cell viability assay}

Cell viability was measured by the MTT method (Mosmann 1983). Cells $\left(4 \times 10^{4}\right.$ cells $/ \mathrm{ml}$ ) were seeded in 96-well plates and pretreated with TSG for $24 \mathrm{~h}$ prior to $\mathrm{MPP}^{+}$exposure. After $24 \mathrm{~h}$ incubation with $\mathrm{MPP}^{+}, 20 \mu \mathrm{l}$ of MTT reagent $(5 \mathrm{mg} / \mathrm{ml}$ MTT in PBS) was added to each well. Following additional $4 \mathrm{~h}$ incubation at $37^{\circ} \mathrm{C}$, the medium was removed and $100 \mu \mathrm{l}$ of DMSO was added to each well to dissolve the formazan crystals. Absorbance was measured at $570 \mathrm{~nm}$ using a microplate reader (Diagnostic Pasteur LP4000, France). The cell viability was expressed as a percentage of the absorbance of control samples, which was assumed to be $100 \%$.

\section{Lactate dehydrogenase assay}

The CytoTox-ONE ${ }^{\mathrm{TM}}$ Homogenous Membrane Integrity Assay Kit with fluorescence readout was used to measure lactate dehydrogenase (LDH) activity 
(Niles et al. 2007). Cells $\left(4 \times 10^{4}\right.$ cells $\left./ \mathrm{ml}\right)$ were seeded in $96-w e l l$ plates and pretreated with TSG for $24 \mathrm{~h}$ prior to $\mathrm{MPP}^{+}$exposure. After the treatment, $100 \mu \mathrm{l}$ of supernatant from each well was transferred to a new 96-well plate for detecting LDH released from cells. The cells remaining in the wells were lysed using CytoTox-ONE lysis buffer in order to measure intracellular LDH. After incubating with assay reagent at room temperature for $10 \mathrm{~min}$, CytoTox-Stop solution was added to the plates to end the reaction. The fluorescence of the plates was read on a SpectraMax M5 (Molecular Devices, Sunnyvale, CA, USA), with an excitation wavelength of $560 \mathrm{~nm}$ and an emission wavelength of $590 \mathrm{~nm}$. The percentage of LDH leakage was calculated using the following formula: LDH leakage $\%=[$ released $\mathrm{LDH} /($ released $\mathrm{LDH}+$ intracellular LDH)] $\times 100 \%$.

\section{Detection of mitochondrial membrane potential}

Mitochondrial membrane potential (MMP) was detected using the fluorescent reagent rhodamine 123 . Cells $\left(1 \times 10^{5}\right.$ cells $\left./ \mathrm{ml}\right)$ were seeded in $60 \mathrm{~mm}$ dishes and were treated with TSG and $\mathrm{MPP}^{+}(200 \mu \mathrm{M})$ as described above. Rhodamine 123 at the final concentration of $10 \mu \mathrm{M}$ was then added to cell cultures and incubated for 30 $\min$ at $37^{\circ} \mathrm{C}$. The cells were washed twice with PBS, collected by pipetting, and then analysed with a flow cytometer (Becton Dickinson, Mountain View, CA, USA). The laser was adjusted to emit at $480 \mathrm{~nm}$, and a $530 \mathrm{~nm}$ long-pass filter was used.

\section{Measurement of intracellular ROS}

Intracellular ROS levels were measured using the fluorescent probe DCFH-DA as previously described (Chen et al. 2010). Cells $\left(4 \times 10^{4}\right.$ cells $\left./ \mathrm{ml}\right)$ were seeded in 
96-well plates and then incubated with TSG for $24 \mathrm{~h}$ prior to $\mathrm{MPP}^{+}$exposure. After stimulation, cells were incubated with $10 \mu \mathrm{M}$ DCFH-DA at $37^{\circ} \mathrm{C}$ for $30 \mathrm{~min}$ and then washed twice with PBS. The fluorescent intensity was measured with a fluorescence microplate reader (Infinite ${ }^{\mathrm{TM}}$ F200, TECAN, Switzerland), with an excitation wavelength of $485 \mathrm{~nm}$ and an emission wavelength of $538 \mathrm{~nm}$.

\section{Western blot assay}

After treating cells as described above, total protein was extracted from cell lysates using RIPA buffer, and protein concentrations were determined with a BCA protein quantitative analysis kit. A total of $40 \mu \mathrm{g}$ of protein was loaded onto a $15 \%$ SDS-polyacrylamide gel for electrophoresis (PAGE) and then transferred to a nitrocellulose membrane (Whatman, New Jersey, USA). The membranes were blocked with 5\% skim milk in Tris-buffered saline (pH 7.4) with $0.1 \%$ Tween-20 for 1 $\mathrm{h}$ at room temperature before overnight incubation with primary antibodies specific for $\alpha$-Syn (1:1000), Bax (1:500), Bcl-2 (1:1000), and $\beta$-actin $(1: 1500)$ in $5 \%$ skim milk-Tris buffered saline Tween (TBST). The membranes were then rinsed 3 times in TBST and incubated with horseradish peroxidase-conjugated secondary IgG (1:2000)

in TBST for $1.5 \mathrm{~h}$, followed by a final series of rinses in TBST. The resulting bands of protein were visualized on Biomax X-ray film (Kodak, Japan) using the Super Signal West Pico Chemiluminescent Kit.

\section{Measurement of caspase-3 activity}

The caspase-3 activity was measured according to the manufacturer's protocol (Beyotime Biotechnology, China). Cells $\left(1 \times 10^{5}\right.$ cells $\left./ \mathrm{ml}\right)$ were seeded in $60 \mathrm{~mm}$ 
dishes and were treated with TSG and $\mathrm{MPP}^{+}$as described above. Cells were lysed with $0.5 \%$ NP-40/10 mM HEPES (pH 7.4) containing 2 mM EDTA, 0.5 mM PMSF, and $5 \mu \mathrm{g} / \mathrm{ml}$ leupeptin. Then, cell lysates were added to $96-w e l l$ microtitre plates and

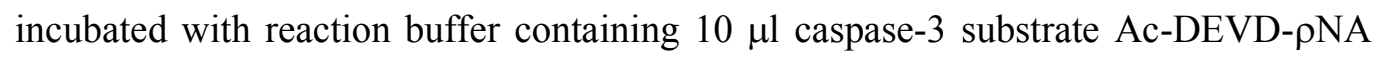
for $4 \mathrm{~h}$ at $37^{\circ} \mathrm{C}$. The absorbance produced by the chromophore $\rho$-nitroanilide was measured at $405 \mathrm{~nm}$. A standard curve was obtained from the absorbances of $\rho$-nitroanilide standard reagent. Protein concentrations were determined by the Bradford method. According to the Chemicon Company (USA), 1 unit of caspase-3 was defined as the amount of enzyme that cleaves $1 \mathrm{nmol}$ of the colourimetric substrate Ac-DEVD- $\rho$ NA per hour at $25^{\circ} \mathrm{C}$ under saturating substrate concentrations. Caspase-3 activity was expressed as units per mg protein.

\section{Flow cytometric detection for apoptotic cells}

The apoptotic rate induced by $\mathrm{MPP}^{+}$was detected by flow cytometry using the Annexin V-FITC/propidium iodide (PI) double-labelling method (Yang et al. 2012). Cells $\left(1 \times 10^{5}\right.$ cells $\left./ \mathrm{ml}\right)$ were seeded in $60 \mathrm{~mm}$ dishes and were treated with TSG and $\mathrm{MPP}^{+}$as described above. Cells were then trypsinized and collected by centrifugation at $800 \mathrm{~g}$ for $5 \mathrm{~min}$. After washing with PBS, cells were then double stained using an Annexin V-FITC apoptosis detection kit. According to the manufacturer's protocol, cells were resuspended in Annexin V-FITC binding buffer, incubated with Annexin V-FITC (at a final concentration of $1 \mu \mathrm{g} / \mathrm{ml}$ ) for $15 \mathrm{~min}$ at room temperature in the dark, and then incubated with PI $(10 \mu \mathrm{g} / \mathrm{ml})$. Samples were analysed with a flow cytometer (Becton Dickinson, USA) by two-parameter dot 
plots.

\section{Immunofluorescence double staining for aggregated $\alpha$-synuclein}

The immunofluorescence double-staining method was used to ascertain the aggregated state of $\alpha$-Syn in cells as previously described (Wang et al. 2015). After fixation with 4\% paraformaldehyde, the cell slides were rinsed in PBS and preincubated with $3 \% \mathrm{H}_{2} \mathrm{O}_{2}$ for 10 min and permeabilized with $0.3 \%$ Triton X-100 in PBS for $30 \mathrm{~min}$. Cell slides were rinsed in PBS for $3 \times 5 \mathrm{~min}$, and then the cells were blocked with $10 \%$ normal goat serum for $40 \mathrm{~min}$ at room temperature. The primary antibody against $\alpha$-Syn (1:600) was added for overnight incubation at $4^{\circ} \mathrm{C}$ in a humidified chamber. After rinsing for $3 \times 5 \mathrm{~min}$ in PBS, the cells were incubated with Cy3-conjugated goat anti-mouse $\operatorname{IgG}(1: 300)$ for $2 \mathrm{~h}$ at room temperature, followed by rinsing for $3 \times 5$ min in PBS. Cell slides were incubated with $0.1 \%$ thioflavin $\mathrm{T}$ in the dark for $8 \mathrm{~min}$ followed by rinsing for $3 \times 5 \mathrm{~min}$ in PBS. Images were captured using a fluorescence microscope (Olympus, Japan). The same light intensity and filters were applied for all images. A negative control, obtained by omitting the primary antibody and applying the secondary antibody alone, was used to confirm the specificity of the immunofluorescence labelling (Supplementary Figure S1).

\section{Statistical analysis}

The results are expressed as the mean \pm standard error of mean (S.E.M.) from at least three independent experiments. For statistical comparisons, quantitative data were analysed by one-way analysis of variance (ANOVA) combined with post-hoc analysis followed by Student's t-test according to the statistical programme Sigma Stat. 
The differences at $P<0.05$ were regarded as statistically significant.

\section{Results}

\section{Effects of TSG on cell damage in A53T $\alpha$-synuclein-transfected cells exposed to} $M_{P P}^{+}$

To determine the optimal conditions for $\mathrm{MPP}^{+}$-induced cellular damage, A53T AS cells or vector control cells were incubated with various concentrations of MPP ${ }^{+}$ for $24 \mathrm{~h}$. The results from MTT assay showed that $\operatorname{MPP}^{+}(25 \sim 800 \mu \mathrm{M})$ induced a significant decrease in cell viability in a dose dependent manner. The inhibition rate in A53T AS cells was higher than that in the vector control cells, indicating that A53T AS cells were more susceptible to $\mathrm{MPP}^{+}$toxicity than vector control cells (Fig. 2A and Supplementary Table S1). Because the cell viability of the A53T AS group was reduced by approximately $40 \%$ after $24 \mathrm{~h}$ incubation with $200 \mu \mathrm{M} \mathrm{MPP}^{+}$, we used this concentration in subsequent experiments.

As illustrated in Fig. 2B, $200 \mu \mathrm{M} \mathrm{MPP}{ }^{+}$exposure for $24 \mathrm{~h}$ decreased the cell viability of A53T AS cells $(P<0.01)$. However, pretreatment with TSG (3.125 - 50 $\mu \mathrm{M})$ for $24 \mathrm{~h}$ prevented cells from $\mathrm{MPP}^{+}$-induced damage and restored cell viability in a dose-dependent manner $(P<0.01)$.

We also investigated the effect of TSG on $\mathrm{MPP}^{+}$-induced cytotoxicity using an LDH assay. The results showed that LDH leakage from A53T AS cells increased after $200 \mu \mathrm{M} \mathrm{MPP}{ }^{+}$exposure for $24 \mathrm{~h}(P<0.01)$. Pretreatment with TSG $(3.125 \sim 50 \mu \mathrm{M})$ for $24 \mathrm{~h}$ decreased LDH leakage from A53T AS cells in a dose dependent manner $(P<0.01)$, demonstrating that TSG prevented cell damage in the complex model of 
A53T AS cells plus MPP ${ }^{+}$exposure (Fig. 2C).

\section{Effects of TSG on $\alpha$-synuclein over-expression and aggregation in A53T}

\section{AS cells exposed to MPP}

Western blot assay was used to detect the expression of $\alpha$-Syn. Fig. 3A and 3B show that the expression levels of $\alpha$-Syn monomer and polymer in A53T AS control cells was higher than that in vector control cells $(P<0.01)$. The expression of $\alpha$-Syn polymer was significantly increased in A53T AS cells after incubation with $200 \mu \mathrm{M}$ $\mathrm{MPP}^{+}$for $24 \mathrm{~h}(P<0.01)$. Pretreatment with TSG $(3.125 \sim 50 \mu \mathrm{M})$ for $24 \mathrm{~h}$ evidently decreased the over-expression of $\alpha$-Syn polymer in A53T AS cells exposed to MPP $(P<0.01)$. Fig. 3C shows the sum of all forms of $\alpha$-Syn. The total amount of $\alpha$-Syn in A53T AS control cells was more than vector control cells $(P<0.01)$, while MPP $^{+}$ exposure further enhanced the increase of total $\alpha$-Syn in A53T AS cells. TSG $(3.125 \sim 50 \mu \mathrm{M})$ obviously declined the total amount of $\alpha$-Syn in a dose-dependent manner in $\mathrm{MPP}^{+}$-treated A53T AS cells $(P<0.01)$. These results demonstrated that TSG significantly inhibited the over-expression and aggregation of $\alpha$-Syn in A53T AS cells.

The immunofluorescence double-staining method was used to ascertain the aggregated state of $\alpha$-Syn in cells. Thioflavin T (ThT) is a cationic benzothiazole dye that displays enhanced fluorescence upon binding to amyloid fibrils. The dye interacts with the specific quaternary structure of the $\beta$-pleated fibril but not the monomeric peptides (WestermarkJohnson and Westermark 1999). The amyloid fibrils fluoresce with an intense green colour, and IgG/Cy3-labeled $\alpha$-Syn fluoresces with a red colour. As shown in Fig. 4, the $\alpha$-Syn fibrils in A53T AS control cells increased slightly 
compared with vector control cells. After $200 \mu \mathrm{M} \mathrm{MPP}^{+}$exposure for $24 \mathrm{~h}$, the $\alpha$-Syn fibrils of A53T AS cells were increased and aggregated. Pretreatment with TSG (25 and $50 \mu \mathrm{M}$ ) for $24 \mathrm{~h}$ markedly inhibited the formation of $\alpha$-Syn fibrils in A53T AS cells exposed to $\mathrm{MPP}^{+}$, further confirming that TSG suppressed the aggregation of $\alpha-S y n$.

\section{Effect of TSG on mitochondrial membrane potential in A53T AS cells exposed to} $\boldsymbol{M P P}^{+}$

Flow cytometry and rhodamine 123 were used to measure mitochondrial membrane potential (MMP). Rhodamine 123 is a cell-permeable, cationic dye that preferentially partitions into mitochondria based on the highly negative MMP. Depolarization of MMP results in the loss of rhodamine 123 from the mitochondria and an increase in intracellular fluorescence (Satoh et al. 1997). As shown in Fig. 5, after incubation with $\mathrm{MPP}^{+}(200 \mu \mathrm{M})$ for $24 \mathrm{~h}$, the fluorescence of rhodamine 123 in A53T AS cells increased $(P<0.01)$, representing a significant decrease in MMP. However, preincubation with TSG $(6.25 \sim 50 \mu \mathrm{M})$ for $24 \mathrm{~h}$ decreased the fluorescence of rhodamine 123 in A53T AS cells exposed to $\mathrm{MPP}^{+}(P<0.05)$, indicating an obvious increase in MMP. These results suggest that TSG may protect mitochondrial functions.

\section{Effect of TSG on reactive oxygen species in A53T AS cells exposed to MPP ${ }^{+}$}

The level of reactive oxygen species (ROS) in cells was measured by using the fluorescent probe DCFH-DA, which can be oxidized to the highly fluorescent compound dichlorofluorescein (DCF). Fig. 6 shows that there was no difference in 
ROS levels between A53T AS control cells and vector control cells without MPP $^{+}$ exposure. The level of ROS in A53T AS cells was increased after $200 \mu \mathrm{M} \mathrm{MPP}$ exposure for $24 \mathrm{~h}(P<0.01)$. However, pretreatment with TSG $(3.125 \sim 50 \mu \mathrm{M})$ for 24 $\mathrm{h}$ attenuated the increase of ROS in A53T AS cells exposed to $\mathrm{MPP}^{+}(P<0.05$, $P<0.01)$.

\section{Effect of TSG on apoptosis and related factors in A53T AS cells exposed to} $\boldsymbol{M P P}^{+}$

Bcl-2 family members are intimately involved in apoptosis. The expression of Bax and Bcl-2 was determined by western blot analysis. As shown in Fig. 7, there were a decline in Bcl-2 expression and a slight elevation in Bax expression in A53T AS control cells compared with vector control cells. Incubation of $200 \mu \mathrm{M} \mathrm{MPP}^{+}$for $24 \mathrm{~h}$ induced an increase in Bax levels and a decrease in Bcl-2 content, thus causing a significant elevation in the ratio of $\mathrm{Bax} / \mathrm{Bcl}-2$ in A53T AS cells $(P<0.05)$. However, TSG $(3.125 \sim 50 \mu \mathrm{M})$ pretreatment for $24 \mathrm{~h}$ suppressed Bax expression and increased Bcl-2 levels, therefore reducing the $\mathrm{Bax} / \mathrm{Bcl}-2$ ratio in a dose dependent manner in A53T cells exposed to $\mathrm{MPP}^{+}(P<0.05, P<0.01)$.

In the presence of caspase-3, the substrate Ac-DEVD- $\rho N A$ is cleaved to form the chromophore $\rho$-nitroanilide, which can be quantified by its colourimetric intensity. Fig. 8 shows that there was no significant difference in caspase-3 activity between A53T AS control cells and vector control cells. Incubation of $200 \mu \mathrm{M} \mathrm{MPP}{ }^{+}$with A53T AS cells for $24 \mathrm{~h}$ induced an increase in the activity of caspase- 3 compared with A53T AS control cells $(P<0.01)$. Pretreatment with TSG $(6.25 \sim 50 \mu \mathrm{M})$ for $24 \mathrm{~h}$ 
decreased the activity of caspase-3 in A53T cells exposed to $\mathrm{MPP}^{+}(P<0.05)$.

Flow cytometry with the Annexin V-FITC/PI double-labelling method was used to detect apoptosis. Annexin $\mathrm{V}$ has a strong affinity for the phospholipid phosphatidylserine, which can translocate from the inner surface of the plasma membrane to the cell surface soon after the initiation of apoptosis (Yan et al. 2009). Fig. 9 displays that there were almost no apoptotic cells in vector control cells and A53T AS control cells. After $200 \mu \mathrm{M} \mathrm{MPP}{ }^{+}$exposure for $24 \mathrm{~h}$, the percentage of apoptotic cells was significantly increased in A53T AS cells $(P<0.01)$. However, pretreatment of TSG $(25$ and $50 \mu \mathrm{M})$ for 24 h obviously reduced the percentage of apoptotic cells in $\mathrm{MPP}^{+}$-treated A53T AS cells $(P<0.05)$.

\section{Discussion}

In the present study, we used a complex model of A53T $\alpha$-synuclein-transfected SH-SY5Y cells (A53T AS cells) plus $\mathrm{MPP}^{+}$exposure to investigate the effects of TSG in an in vitro cellular model of PD that encompassed both genetic and environmental factors. We found that the expression and aggregation of $\alpha$-Syn increased significantly in A53T AS control cells compared with vector control cells. $\mathrm{MPP}^{+}$, a powerful inhibitor of mitochondria complex I, further promoted $\alpha$-Syn aggregation in A53T AS cells, and induced more severe damage to A53T AS cells than to the vector control cells. These results indicate that over-expression and aggregation of $\alpha$-Syn increases the sensitivity of cells to $\mathrm{MPP}^{+}$neurotoxicity. We used the complex model of A53T AS cells plus $\mathrm{MPP}^{+}$exposure to investigate the 
effects of TSG in the following experiments. The results showed that TSG significantly inhibited $\alpha$-Syn over-expression and aggregation; elevated the mitochondrial membrane potential; decreased ROS level, the Bax/Bcl-2 ratio and caspase-3 activity; and inhibited apoptosis. Thus, TSG reduced cellular damage, which was further confirmed by an increase in cell viability and decreased LDH leakage in A53T AS cells exposed to $\mathrm{MPP}^{+}$.

$\alpha$-Synuclein, a major component of the intra-neuronal Lewy body aggregates, is a highly conserved protein containing 140 amino acids that is mainly expressed in neurons and is concentrated in presynaptic nerve terminals (Jakes et al. 1994; George et al. 1995). Accumulation of $\alpha$-Syn is implicated in the pathogenesis of both familiar and sporadic PD (Lan et al. 2012). Recently, the relationship between MPP neurotoxicity and $\alpha$-Syn expression has caused extensive concern. For example, knockdown of $\alpha$-Syn protected SH-SY5Y cells against $\mathrm{MPP}^{+}$neurotoxicity (Wu et al. 2009). The A53T mutation of $\alpha$-Syn promoted its aggregation, which further initiated oxidative stress and nitration injury (Giasson et al. 2000). In the present study, $\alpha$-Syn expression was higher in A53T AS control cells than that in vector control cells. $\mathrm{MPP}^{+}$further promoted the over-expression and aggregation of $\alpha$-Syn in A53T AS cells. These findings are in accordance with other investigators' reports (Fan et al. 2006). TSG inhibited the over-expression and aggregation of $\alpha$-Syn in A53T AS cells exposed to $\mathrm{MPP}^{+}$, suggesting that TSG may have the potential to treat synucleinopathy such as PD and DLB.

Mitochondrial dysfunction is one of the major pathogenic mechanisms of PD 
(Dawson and Dawson 2003). Some transgenic mice over-expressing $\alpha$-Syn presented with abnormal mitochondrial morphology (Stichel et al. 2007; Martin et al. 2006), while $\alpha$-synuclein knockdown prevented $\mathrm{MPP}^{+}$-induced mitochondrial fragmentation in SH-SY5Y cells (Zhao et al. 2007). The mitochondrial membrane potential is a highly sensitive indicator of the energy state of mitochondria and is also a central regulator of cell health (Perry et al. 2011). $\mathrm{MPP}^{+}$accumulates in the mitochondria, resulting in ATP depletion and mitochondrial membrane potential alteration (Ghosh et al. 2010). In the present study, results showed that $\mathrm{MPP}^{+}$decreased mitochondrial membrane potential in A53T AS cells, while the pretreatment with TSG significantly increased mitochondrial membrane potential in A53T AS cells exposed to $\mathrm{MPP}^{+}$. These results suggest that TSG may protect mitochondrial function, which may be beneficial for PD therapy.

Oxidative stress plays an important role in the pathogenesis and progression of PD (Dauer and Przedborski 2003). MPP ${ }^{+}$increases ROS production, thus inducing cell damage (Blesa et al. 2015). Numerous studies have shown that the over-expression and aggregation of $\alpha$-Syn impair mitochondrial complex I activity [(Loeb et al. 2010; Stichel et al. 2007)], and $\alpha$-Syn may directly interact with complex I to exert this effect (Devi et al. 2008). In the present study, we found that MPP induced a significant increase in ROS level in A53T AS cells, and TSG suppressed the levels of ROS in A53T AS cells exposed to $\mathrm{MPP}^{+}$. This result demonstrated that TSG had antioxidant properties, which might be one of the mechanisms of TSG's neuroprotective effect. 
Apoptosis is regulated by $\mathrm{Bcl}-2$ families and caspases. The Bcl-2 family comprises anti-apoptotic members (such as Bcl-2, and Bcl-XL) and pro-apoptotic proteins (such as Bax, Bak, and Bid) (Sadoul 1998). Among the identified caspases, caspase- 3 is thought to be the key enzyme that induces apoptosis and is the ultimate enforcer of caspases in apoptosis (Chen et al. 2015). The induced expression of A53T $\alpha$-Syn in differentiated PC12 cells increased the intracellular ROS levels, which is accompanied by mitochondrial cytochrome $\mathrm{C}$ release and an elevation in caspase- 9 and caspase-3 activities (Liu et al. 2011). $\alpha$-Synuclein over-expression may result in cytotoxicity by decreasing Bcl-XL expression and increasing Bax expression (Seo et al. 2002). Mitochondrial dysfunction contributed to A53T $\alpha$-Syn-induced cell death (Smith et al. 2005). Furthermore, MPTP induced pro-apoptotic Bax, while transgenic mice deficient in Bax and those over-expressing Bcl-2 were resistant to MPTP toxicity in vivo (Vila et al. 2000). In the present study, we found that $\mathrm{MPP}^{+}$exposure increased the ratio of Bax to Bcl-2 and the activity of caspase-3 in A53T AS cells. TSG pretreatment significantly decreased the ratio of Bax/Bcl-2 and the activity of caspase-3, thus inhibiting apoptosis in A53T AS cells exposed to MPP ${ }^{+}$.

Our previous study found that TSG protected SH-SY5Y cells against $\mathrm{MPP}^{+}$-induced cell death through decreasing oxidative stress and inhibiting apoptosis (Sun et al. 2011). Some other investigators also reported that TSG attenuated $\mathrm{MPP}^{+}$-induced apoptosis in PC12 cells by inhibiting ROS generation and modulating JNK activation ( $\mathrm{Li}$ et al. 2010) or by activating PI3K/Akt signalling pathway (Qin et al. 2011). But all these cells used in above studies were normal cells. In our previous 
study, we discovered that incubation of $\alpha$-synuclein-transfected PC12 cells with TSG for $24 \mathrm{~h}$ inhibited the expression and aggregation of $\alpha$-synuclein via up-regulating ubiquitin-proteasome system ( Liu et al. 2012), suggesting that $\alpha$-synuclein may be a potential target of TSG. In the present study, we incubated $\alpha$-synuclein-transfected SH-SY5Y cells with TSG for $24 \mathrm{~h}$, at this time TSG might have already decreased the content and aggregation of $\alpha$-synuclein. Then the medium was removed and MPP was added and incubated for $24 \mathrm{~h}$, which meant that $\mathrm{MPP}^{+}$-induced oxidative stress and apoptosis occurred late. According to the experiment flow and combining the results of our previous study, we speculate that TSG may inhibit the over-expression and aggregation of $\alpha$-synuclein first; based on this effect, TSG exerts stronger neuroprotection against $\mathrm{MPP}^{+}$-induced oxidative stress and apoptosis.

In conclusion, results of the present study showed that A53T AS cells were more vulnerable to $\mathrm{MPP}^{+}$neurotoxicity than the vector control cells. TSG protected cells against $\mathrm{MPP}^{+}$-induced cell damage in A53T AS cells, and the mechanisms of TSG's neuroprotective effects were mediated by inhibiting $\alpha$-Syn over-expression and aggregation, enhancing mitochondria function, reducing ROS level, and inhibiting apoptosis via reductions in the $\mathrm{Bax} / \mathrm{Bcl}-2$ ratio and caspase-3 activity in A53T AS cells exposed to $\mathrm{MPP}^{+}$. These results suggest that TSG may be beneficial for PD therapy.

\section{Acknowledgements}

This research was supported by the National Natural Science Foundation of 
China (No. 81273498, No. 81341087 and No. 81473373), National Science and Technology Major Project for New Drug Research and Development of China (No. 2015ZX09101-016), Beijing Natural Science Foundation (No. 7132110), Beijing Health and Technical High-level Personal Plan (No. 2011-1-7 and No. 2014-2-014), and the Capital Health Research and Development (No. 2011-1001-04 and No. 2016-2-1033). We thank Ya-li Li, Li Zhang, Yan-Chuan Wu and Hou-xi Ai for technical assistance.

\section{Conflict of interest}

The authors declare that there are no conflicts of interest associated with this manuscript.

\section{References}

Blesa, J., Trigo-Damas, I., Quiroga-Varela, A., and Jackson-Lewis, V. R. 2015. Oxidative stress and Parkinson's disease. Front. Neuroanat. 9: 91.

Chen, R., Liu, S., Piao, F., Wang, Z., Qi, Y., and Li, S., et al. 2015. 2,5-hexanedione induced apoptosis in mesenchymal stem cells from rat bone marrow via mitochondria-dependent caspase-3 pathway. Ind. Health, 53(3): 222-235.

Chen, Y. J., Huang, X. B., Li, Z. X., Yin, L. L., Chen, W. Q., and Li, L. 2010. Tenuigenin protects cultured hippocampal neurons against methylglyoxal-induced neurotoxicity. Eur. J. Pharmacol. 645(1-3): 1-8.

Dauer, W., and Przedborski, S. 2003. Parkinson's disease: mechanisms and models. 
Neuron, 39(6), 889-909.

Dawson, T. M., and Dawson, V. L. 2003. Molecular pathways of neurodegeneration in Parkinson's disease. Science, 302(5646): 819-822.

Devi, L., Raghavendran, V., Prabhu, B. M., Avadhani, N. G., and Anandatheerthavarada, H. K. 2008. Mitochondrial import and accumulation of alpha-synuclein impair complex $\mathrm{I}$ in human dopaminergic neuronal cultures and Parkinson disease brain. J. Biol. Chem. 283(14): 9089-9100.

Fan, G. H., Zhou, H. Y., Yang, H., and Chen, S. D. 2006. Heat shock proteins reduce alpha-synuclein aggregation induced by $\mathrm{MPP}^{+}$in SK-N-SH cells. FEBS Lett. 580(13): 3091-3098.

George, J. M., Jin, H., Woods, W. S., and Clayton, D. F. 1995. Characterization of a novel protein regulated during the critical period for song learning in the zebra finch. Neuron, 15(2): 361-372.

Ghosh, A., Chandran, K., Kalivendi, S. V., Joseph, J., Antholine, W. E., and Hillard, C. J., et al. 2010. Neuroprotection by a mitochondria-targeted drug in a Parkinson's disease model. Free Radic. Biol. Med. 49(11): 1674-1684.

Giasson, B. I., Duda, J. E., Murray, I. V., Chen, Q., Souza, J. M., and Hurtig, H. I., et al. 2000. Oxidative damage linked to neurodegeneration by selective alpha-synuclein nitration in synucleinopathy lesions. Science, 290(5493): 985-989.

Gomez-Santos, C., Ferrer, I., Reiriz, J., Vinals, F., Barrachina, M., and Ambrosio, S. 2002. $\mathrm{MPP}^{+}$increases alpha-synuclein expression and ERK/MAP-kinase phosphorylation in human neuroblastoma SH-SY5Y cells. Brain Res. 935(1-2): 
32-39.

Horowitz, M. P., and Greenamyre, J. T. 2010. Gene-environment interactions in Parkinson's disease: the importance of animal modeling. Clin. Pharmacol. Ther. 88(4): 467-474.

Jakes, R., Spillantini, M. G., and Goedert, M. 1994. Identification of two distinct synucleins from human brain. FEBS Lett. 345(1): 27-32.

Johnson, M. E., and Bobrovskaya, L. 2015. An update on the rotenone models of Parkinson's disease: their ability to reproduce the features of clinical disease and model gene-environment interactions. Neurotoxicology, 46: 101-116.

Lan, D. M., Liu, F. T., Zhao, J., Chen, Y., Wu, J. J., and Ding, Z. T., et al. 2012. Effect of trehalose on PC12 cells overexpressing wild-type or A53T mutant alpha-synuclein. Neurochem. Res. 37(9): 2025-2032.

Li, X., Li, Y., Chen, J., Sun, J., Li, X., and Sun, X., et al. 2010. Tetrahydroxystilbene glucoside attenuates $\mathrm{MPP}^{+}$-induced apoptosis in PC12 cells by inhibiting ROS generation and modulating JNK activation. Neurosci. Lett. 483(1): 1-5.

Liu, Y., Li, L. and Zhang, L. 2012. Effects of tetrahydroxystilbene glucoside on over-expression of $\alpha$-synuclein and ubiquitin-proteasome system in $\alpha$-synuclein transfected PC12 cells. Chin. Pharmacol. J. 47(1): 34-39.

Liu, Z., Yu, Y., Li, X., Ross, C. A., and Smith, W. W. 2011. Curcumin protects against A53T alpha-synuclein-induced toxicity in a PC12 inducible cell model for Parkinsonism. Pharmacol. Res. 63(5): 439-444.

Loeb, V., Yakunin, E., Saada, A., and Sharon, R. 2010. The transgenic overexpression 
of alpha-synuclein and not its related pathology associates with complex I inhibition. J. Biol. Chem. 285(10): 7334-7343.

Martin, L. J., Pan, Y., Price, A. C., Sterling, W., Copeland, N. G., and Jenkins, N. A., et al. 2006. Parkinson's disease alpha-synuclein transgenic mice develop neuronal mitochondrial degeneration and cell death. J. Neurosci. 26(1): 41-50.

Moon, H. E., and Paek, S. H. 2015. Mitochondrial dysfunction in Parkinson's disease. Exp. Neurobiol. 24(2): 103-116.

Mosmann, T. 1983. Rapid colorimetric assay for cellular growth and survival: application to proliferation and cytotoxicity assays. J. Immunol. Methods, 65(1-2): $55-63$.

Niles, A. L., Moravec, R. A., Eric, H. P., Scurria, M. A., Daily, W. J., and Riss, T. L. 2007. A homogeneous assay to measure live and dead cells in the same sample by detecting different protease markers. Anal. Biochem. 366(2): 197-206.

Ozansoy, M., and Basak, A. N. 2013. The central theme of Parkinson's disease: alpha-synuclein. Mol. Neurobiol. 47(2): 460-465.

Perry, S. W., Norman, J. P., Barbieri, J., Brown, E. B., and Gelbard, H. A. 2011. Mitochondrial membrane potential probes and the proton gradient: a practical usage guide. Biotechniques, 50(2): 98-115.

Qian, J. J., Cheng, Y. B., Yang, Y. P., Mao, C. J., Qin, Z. H., and Li, K., et al. 2008. Differential effects of overexpression of wild-type and mutant human alpha-synuclein on $\mathrm{MPP}^{+}$-induced neurotoxicity in PC12 cells. Neurosci. Lett. 435(2): 142-146.

Qin, R., Li, X., Li, G., Tao, L., Li, Y., and Sun, J., et al. 2011. Protection by 
tetrahydroxystilbene glucoside against neurotoxicity induced by $\mathrm{MPP}^{+}$: the involvement of PI3K/Akt pathway activation. Toxicol. Lett. 202(1): 1-7.

Sadoul, R. 1998. Bcl-2 family members in the development and degenerative pathologies of the nervous system. Cell Death Differ. 5(10): 805-815.

Satoh, T., Enokido, Y., Aoshima, H., Uchiyama, Y., and Hatanaka, H. 1997. Changes in mitochondrial membrane potential during oxidative stress-induced apoptosis in PC12 cells. J. Neurosci. Res. 50(3): 413-420.

Seo, J. H., Rah, J. C., Choi, S. H., Shin, J. K., Min, K., and Kim, H. S., et al. 2002. Alpha-synuclein regulates neuronal survival via Bcl-2 family expression and PI3/Akt kinase pathway. FASEB J. 16(13): 1826-1828.

Smith, W. W., Jiang, H., Pei, Z., Tanaka, Y., Morita, H., and Sawa, A., et al. 2005. Endoplasmic reticulum stress and mitochondrial cell death pathways mediate A53T mutant alpha-synuclein-induced toxicity. Hum. Mol. Genet. 14(24): 3801-3811.

Spira, P. J., Sharpe, D. M., Halliday, G., Cavanagh, J., and Nicholson, G. A. 2001. Clinical and pathological features of a Parkinsonian syndrome in a family with an Ala53Thr alpha-synuclein mutation. Ann. Neurol. 49(3): 313-319.

Stichel, C. C., Zhu, X. R., Bader, V., Linnartz, B., Schmidt, S., and Lubbert, H. 2007. Mono- and double-mutant mouse models of Parkinson's disease display severe mitochondrial damage. Hum. Mol. Genet.16(20): 2377-2393.

Sun, F. L., Zhang, L., Zhang, R. Y., and Li, L. 2011. Tetrahydroxystilbene glucoside protects human neuroblastoma SH-SY5Y cells against $\mathrm{MPP}^{+}$-induced cytotoxicity. Eur. J. Pharmacol. 660(2-3): 283-290. 
Vila, M., Vukosavic, S., Jackson-Lewis, V., Neystat, M., Jakowec, M., and Przedborski, S. 2000. Alpha-synuclein up-regulation in substantia nigra dopaminergic neurons following administration of the parkinsonian toxin MPTP. J. Neurochem. 74(2): 721-729.

Wang, R., Tang, Y., Feng, B., Ye, C., Fang, L., and Zhang, L., et al. 2007. Changes in hippocampal synapses and learning-memory abilities in age-increasing rats and effects of tetrahydroxystilbene glucoside in aged rats. Neuroscience, 149(4): 739-746. Wang, R., Zhao, J., Zhang, J., Liu, W., Zhao, M., and Li, J., et al. 2015. Effect of lysosomal and ubiquitin-proteasome system dysfunction on the abnormal aggregation of alpha-synuclein in PC12 cells. Exp. Ther. Med. 9(6): 2088-2094.

Westermark, G. T., Johnson, K. H., and Westermark, P. 1999. Staining methods for identification of amyloid in tissue. Methods Enzymol. 309: 3-25.

Wu, F., Poon, W. S., Lu, G., Wang, A., Meng, H., and Feng, L., et al. 2009. Alpha-synuclein knockdown attenuates $\mathrm{MPP}^{+}$induced mitochondrial dysfunction of SH-SY5Y cells. Brain Res. 1292: 173-179.

Xu, J., Wei, C., Xu, C., Bennett, M. C., Zhang, G., and Li, F., et al. 2007. Rifampicin protects PC12 cells against $\mathrm{MPP}^{+}$-induced apoptosis and inhibits the expression of an alpha-Synuclein multimer. Brain Res. 1139: 220-225.

Yan, H. L., Xue, G., Mei, Q., Wang, Y. Z., Ding, F. X., and Liu, M. F., et al. 2009. Repression of the miR-17-92 cluster by p53 has an important function in hypoxia-induced apoptosis. EMBO J. 28(18): 2719-2732.

Yang, G., Zhou, X., Wang, J., Zhang, W., Zheng, H., and Lu, W., et al. 2012. 
MEHP-induced oxidative DNA damage and apoptosis in HepG2 cells correlates with p53-mediated mitochondria-dependent signaling pathway. Food Chem. Toxicol. 50(7): 2424-2431.

Zhang, L., Yu, S., Zhang, R., Xing, Y., Li, Y., and Li, L. 2013. Tetrahydroxystilbene glucoside antagonizes age-related alpha-synuclein overexpression in the hippocampus of APP transgenic mouse model of Alzheimer's disease. Restor. Neurol. Neurosci. 31(1): 41-52.

Zhao, D. L., Zou, L. B., Zhou, L. F., Zhu, P., and Zhu, H. B. 2007. A cell-based model of alpha-synucleinopathy for screening compounds with therapeutic potential of Parkinson's disease. Acta Pharmacol. Sin. 28(5): 616-626. 


\section{Figure legends}

Fig. 1. Structure of 2, 3, 5, 4'- tetrahydroxystilbene--2-O- $\beta$-D-glucoside (TSG).

Fig. 2. Effects of TSG on cell damage in A53T $\alpha$-synuclein-transfected cells exposed to MPP $^{+}$. (A) Cell viability was measured using the MTT assay. The inhibition rate $=100 \%-$ cell viability\%. Data represent mean \pm S.E.M. of 5 independent experiments. ${ }^{* *} P<0.01$, compared with the vector control group without $\mathrm{MPP}^{+}$exposure. ${ }^{\#} P<0.01$, compared with the A53T AS cells without $\mathrm{MPP}^{+}$exposure. ${ }^{\triangle \triangle} P<0.01,{ }^{\triangle} P<0.05$, compared with vector control cells at the same $\mathrm{MPP}^{+}$ concentration.

(B) Effect of TSG on cell viability. Cell viability was assessed using the MTT assay. Data represent mean \pm S.E.M of 5 independent experiments. ${ }^{\triangle} P<0.01$, (A53T AS cells $+\mathrm{MPP}^{+}$) model group vs. A53T AS control group; $* * P<0.01$, TSG group $v s$. (A53T AS cells $+\mathrm{MPP}^{+}$) model group. (C) Effect of TSG on LDH leakage of A53T AS cells exposed to $\mathrm{MPP}^{+}$. Released lactate dehydrogenase (LDH) activity and total LDH activity were measured to calculate the percentage of LDH leakage. Data represent mean \pm S.E.M. of 3 independent experiments. ${ }^{\triangle} P<0.01$, (A53T AS cells + $\mathrm{MPP}^{+}$) model group vs. A53T AS control group, ${ }^{* *} P<0.01$, TSG group $v s$. (A53T AS cells $+\mathrm{MPP}^{+}$) model group.

Fig.3. Effects of TSG on $\alpha$-synuclein over-expression and aggregation in A53T AS cells exposed to MPP $^{+}$. A53T AS cells were pretreated with TSG for $24 \mathrm{~h}$ before $200 \mu \mathrm{M} \mathrm{MPP}^{+}$exposure for $24 \mathrm{~h}$. Western blot assay was used to detect the 
level of $\alpha$-synuclein ( $\alpha$-Syn) in cells. (A) Representative image of immunoblots of $\alpha$-Syn. (B) Quantitative analysis of $\alpha$-Syn momomer and polymer. (C) The sum of all forms of $\alpha$-Syn. Data represent mean \pm S.E.M. of 3 independent experiments. ${ }^{\# \#} P<0.01$, A53T AS control cells $v s$. vector control group. ${ }^{\triangle \triangle} P<0.01$, (A53T AS cells $+\mathrm{MPP}^{+}$) model group $v s$. A53T AS control cells; ${ }^{*} P<0.05, * * P<0.01$, TSG group $v s$. (A53T AS cells $+\mathrm{MPP}^{+}$) model group.

Fig.4. Immunofluorescence double staining of aggregated $\boldsymbol{\alpha}$-Syn. IgG-Cy3 labeled $\alpha$-Syn fluoresces with a red color, and thioflavin T (ThT)-labeled amyloid fibrils fluoresce with an intense green color. Scale bar $=50 \mu \mathrm{m}$.

Fig.5. Effect of TSG on mitochondrial membrane potential (MMP) of A53T AS cells exposed to $\mathrm{MPP}^{+}$. A53 T AS cells were pretreated with TSG for $24 \mathrm{~h}$ before 200 $\mu \mathrm{M} \mathrm{MPP}^{+}$exposure for $24 \mathrm{~h}$. Cells were loaded with rhodamine 123 , and fluorescence was monitored by flow cytometry. An increase in the intracellular fluorescence of rhodamine 123 indicates a decrease in MMP, and vice versa. (A) A representative set of flow cytometric histograms. a) Vector control cells. b) A53T $\alpha$-synuclein-transfected control cells. c) (A53T AS cells $\left.+\mathrm{MPP}^{+}\right)$model. d $\left.\sim \mathrm{h}\right)$

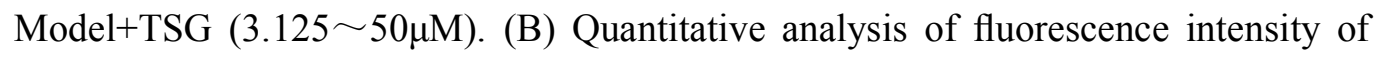
rhodamine 123. Data represent mean \pm S.E.M. of 4 experiments. ${ }^{\triangle} P<0.01$, (A53T AS cells $+\mathrm{MPP}^{+}$) model group $v s$. A53T AS control group; $* P<0.05$, TSG group $v s$. (A53T AS cells $+\mathrm{MPP}^{+}$) model group. 
Fig. 6. Effect of TSG on reactive oxygen species (ROS) in A53T AS cells exposed to MPP $^{+}$. The ROS level was reflected by fluorescent intensity of dichlorofluorescin (DCF). Data represent mean \pm S.E.M. of 3 independent experiments. ${ }^{\Delta \triangle} P<0.01$, $\left(\right.$ A53T AS cells $+\mathrm{MPP}^{+}$) model cells $v$. A53T AS control cells; $* P<0.05, * * P<0.01$, TSG group vs. (A53T AS cells $+\mathrm{MPP}^{+}$) model group.

Fig.7. Effect of TSG on the expression of Bax and Bcl-2 in A53T AS cells exposed to $\mathrm{MPP}^{+}$. A53T AS cells were pretreated with TSG for $24 \mathrm{~h}$ before $200 \mu \mathrm{M} \mathrm{MPP}$ exposure for $24 \mathrm{~h}$. The levels of Bax and Bcl-2 in cell lysates were determined by western blot analysis. (A) Representative image of immunoblots for Bax and Bcl-2. (B) The Bax/Bcl-2 ratio was quantified by densitometric analysis. The Bax/Bcl-2 ratio in vector control cells was set as $100 \%$. Data represent mean \pm S.E.M. of 3 experiments. ${ }^{\triangle} P<0.05$, (A53T AS cells $+\mathrm{MPP}^{+}$) model group vs. A53T AS control group. ${ }^{*} P<0.05,{ }^{*} P<0.01$, TSG group $v s$. (A53T AS cells $+\mathrm{MPP}^{+}$) model group.

Fig. 8. Effect of TSG on caspase-3 activity in A53T AS cells exposed to MPP ${ }^{+}$. Caspase-3 activity was expressed as units per mg protein. Data represent mean \pm S.E.M. of 3 experiments. ${ }^{\triangle \triangle} P<0.01$, (A53T AS cells + MPP $^{+}$) model group vs. A53T AS control group. ${ }^{*} P<0.05$, TSG group vs. (A53T AS cells $+\mathrm{MPP}^{+}$) model group.

Fig.9. Effect of TSG on apoptosis in A53T AS cells exposed to MPP ${ }^{+}$. (A) A representative set of flow cytometric two-parameter dot-plots. The lower left quadrant 
of the cytograms displays the viable cells, the lower right quadrant represents early apoptotic cells, and the upper right quadrant represents cells in the end stages of apoptosis and necrosis. (B) The percentage of apoptotic cells. Data represent mean \pm S.E.M. of 3 experiments. ${ }^{\triangle \Delta} P<0.01$, (A53T AS cells + MPP $^{+}$) model group vs. A53T AS control group. ${ }^{*} P<0.05$, TSG group vs. (A53T AS cells $+\mathrm{MPP}^{+}$) model group. 
Fig. 1. Structure of 2, 3, 5, 4'- tetrahydroxystilbene--2-O- $\beta$-D-glucoside (TSG).

Molecular weight: 406

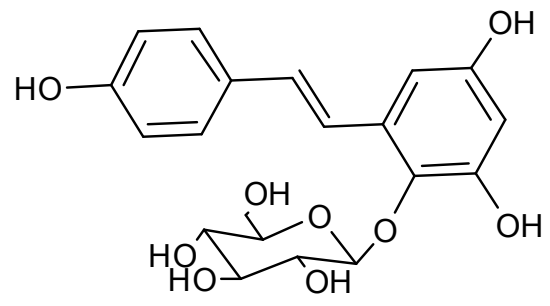


Fig.2

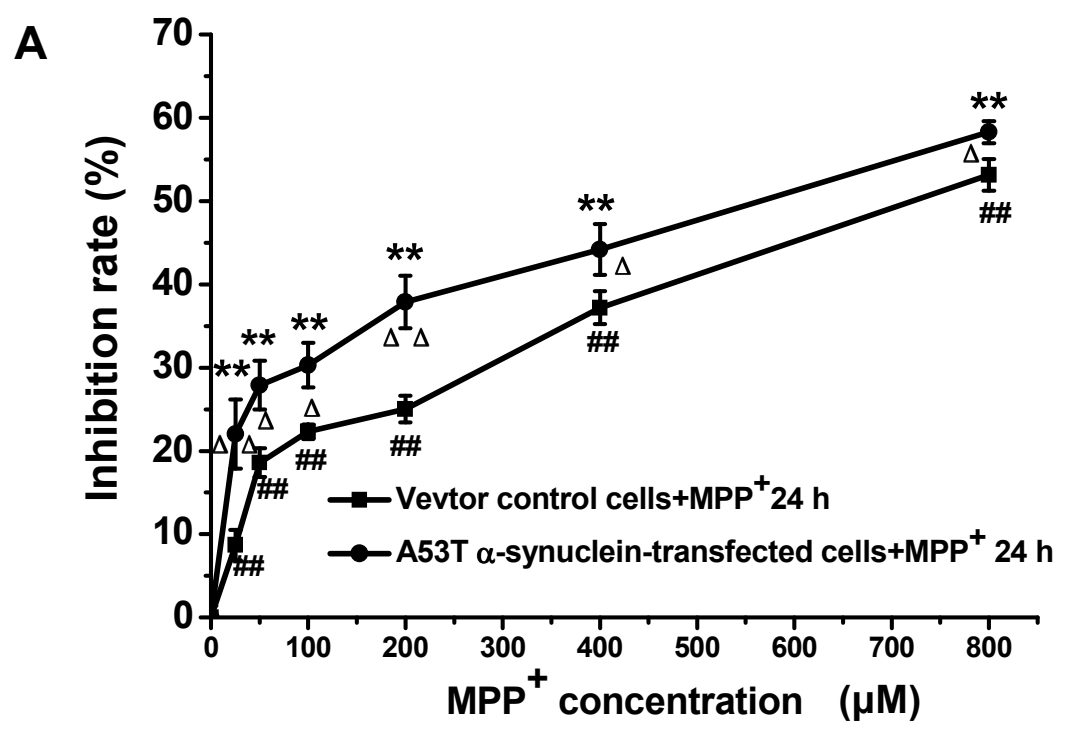

B

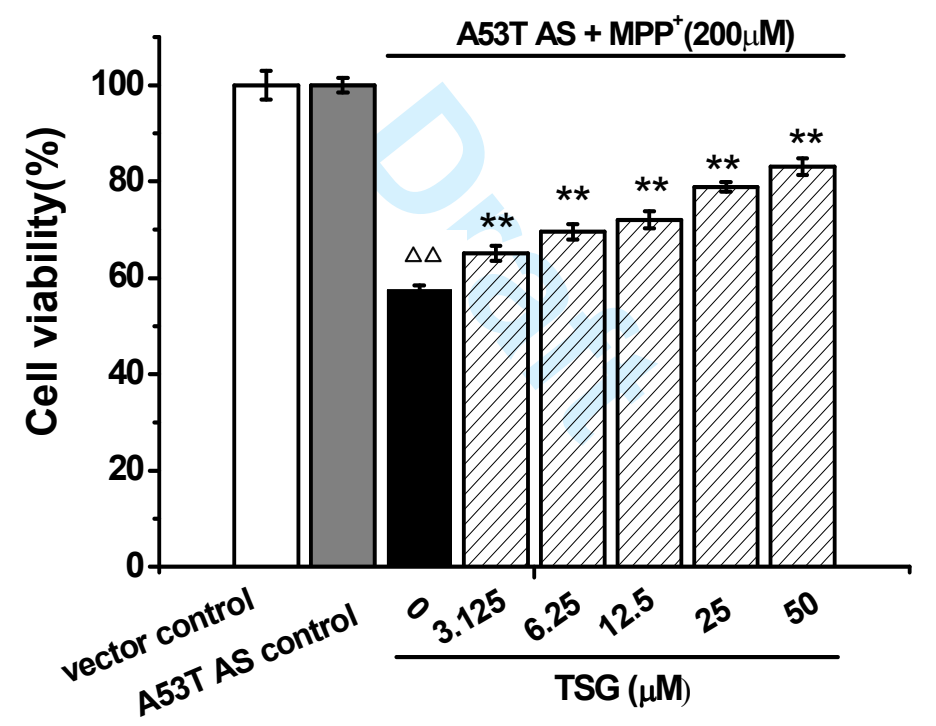

C

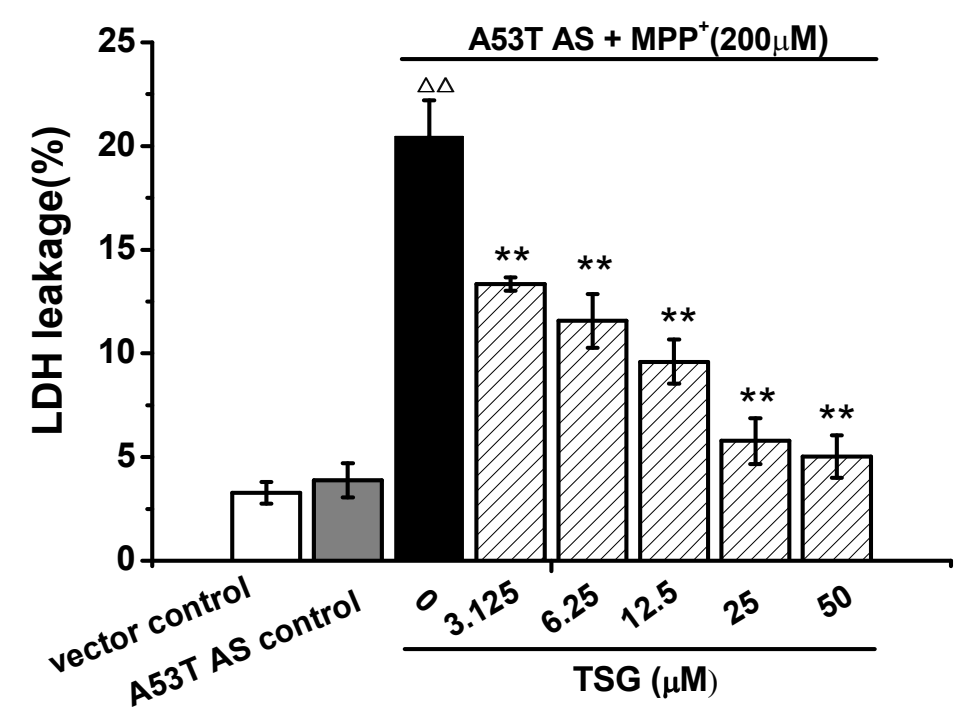

https://mc06.manuscriptcentral.com/cjpp-pubs 
Fig.3

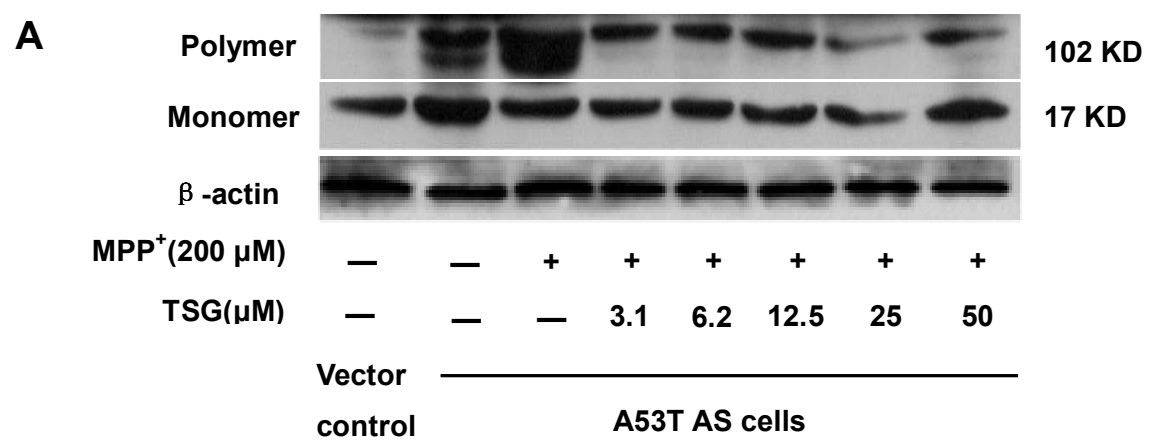

B

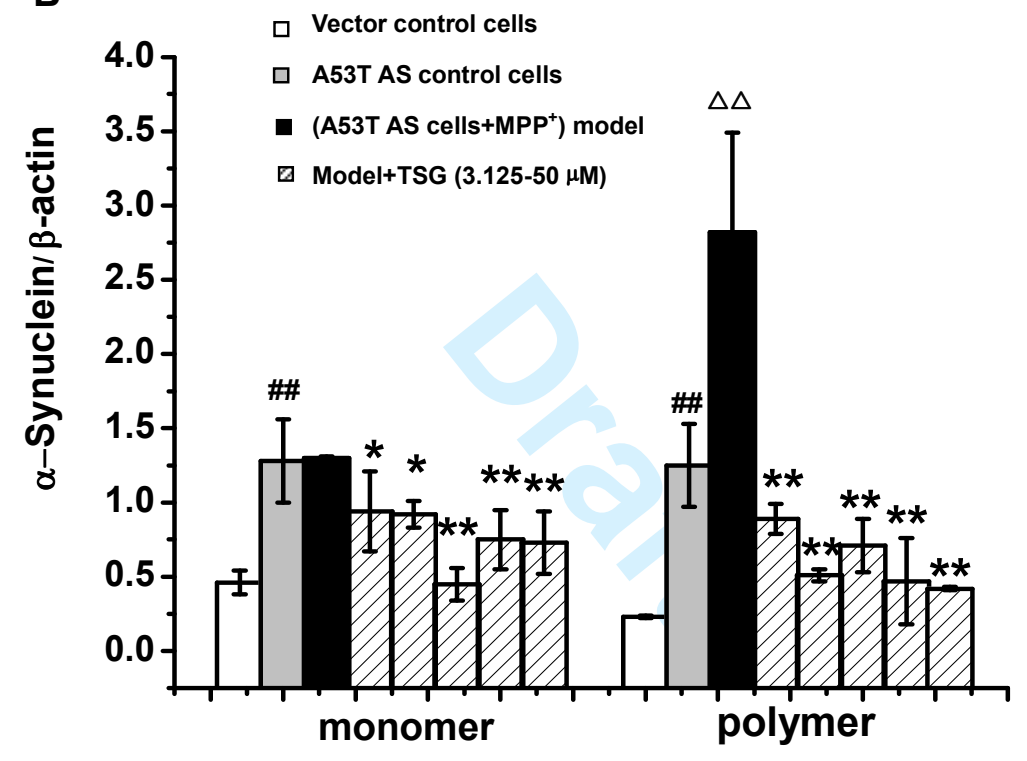

C

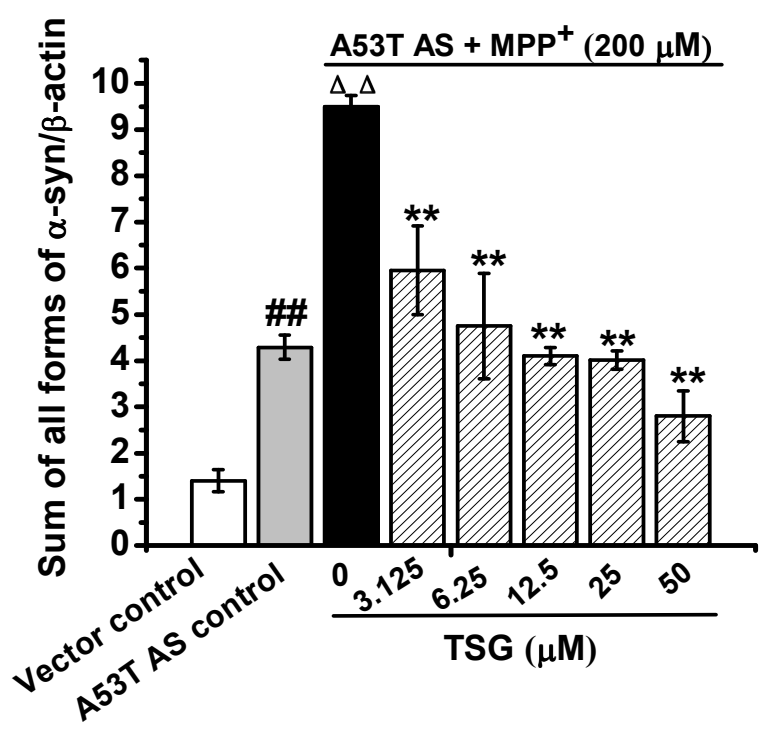


Fig.4

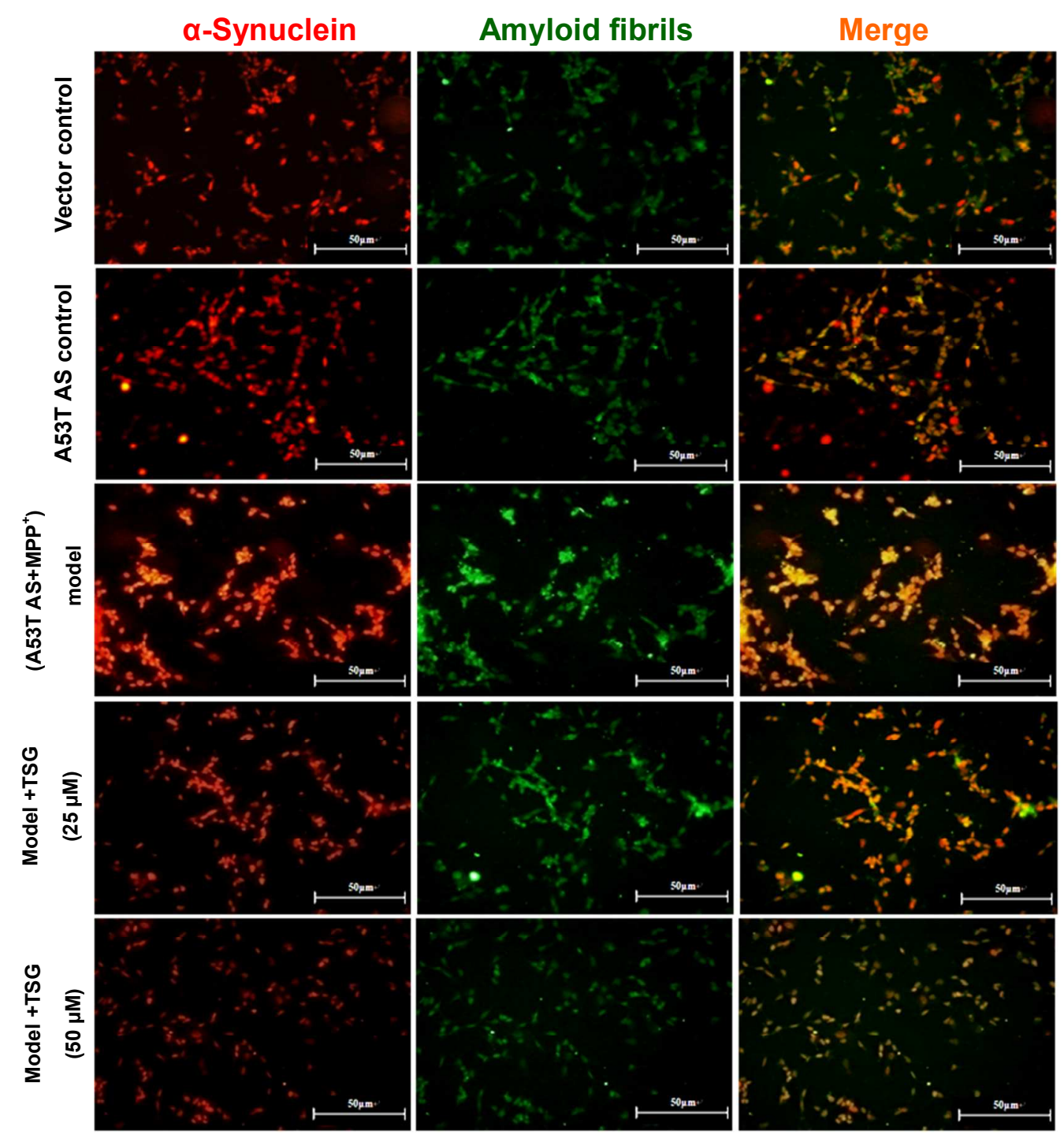


Fig.5

A

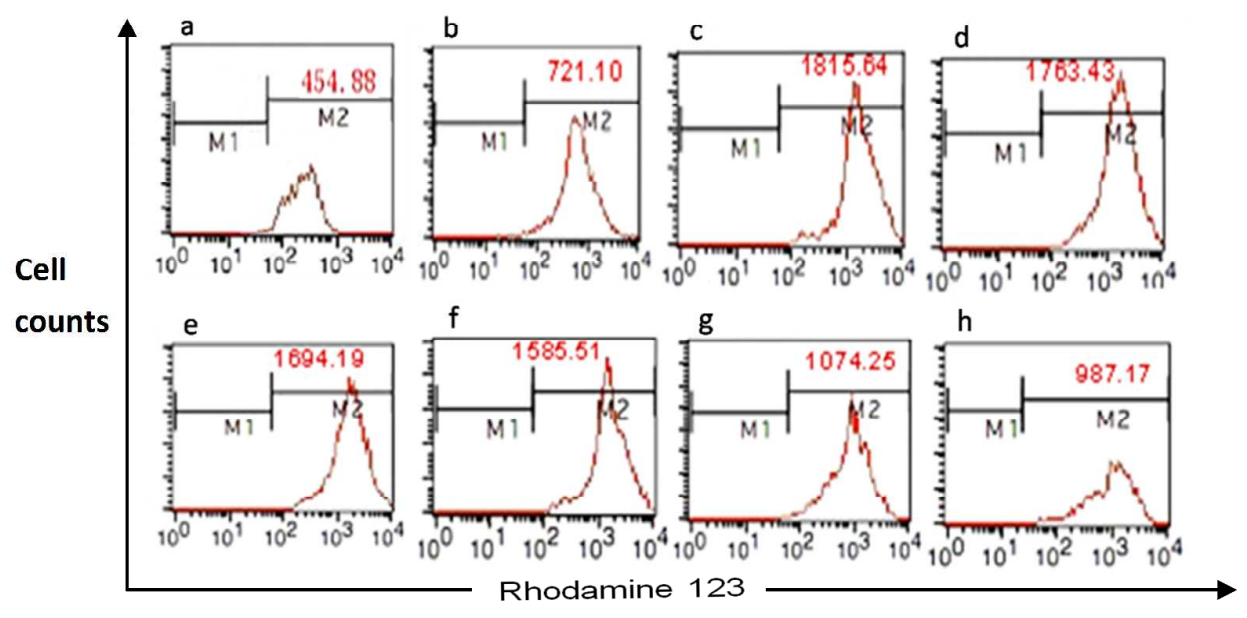

B

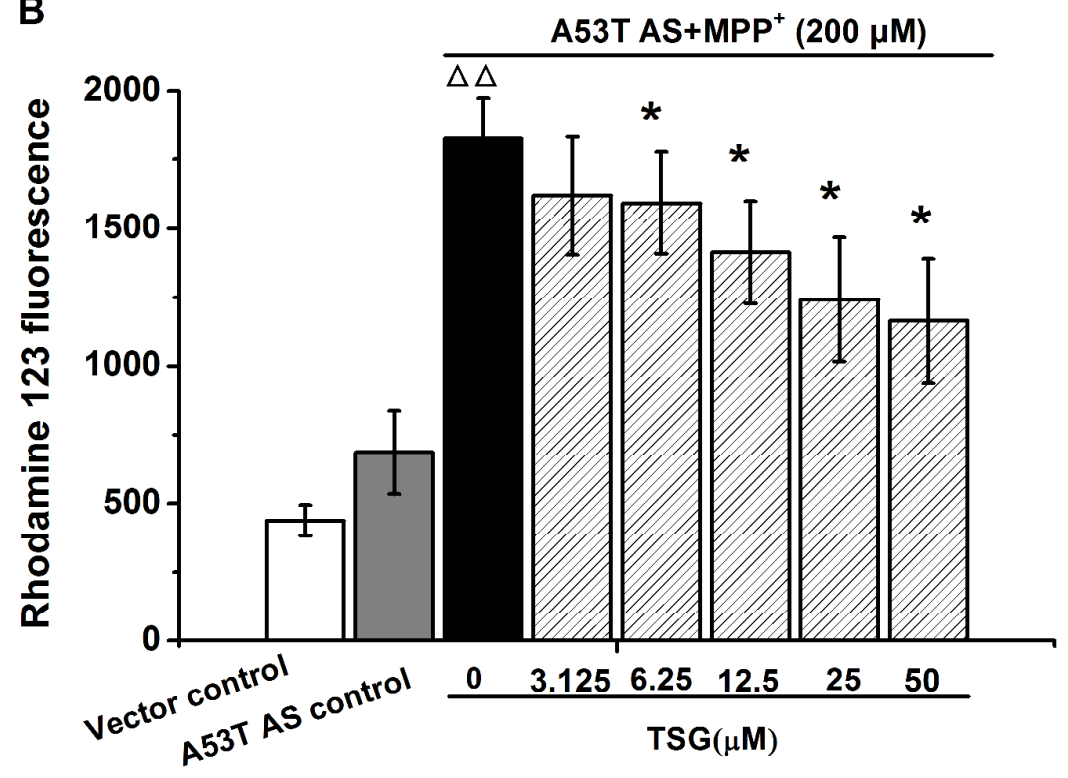


Fig.6

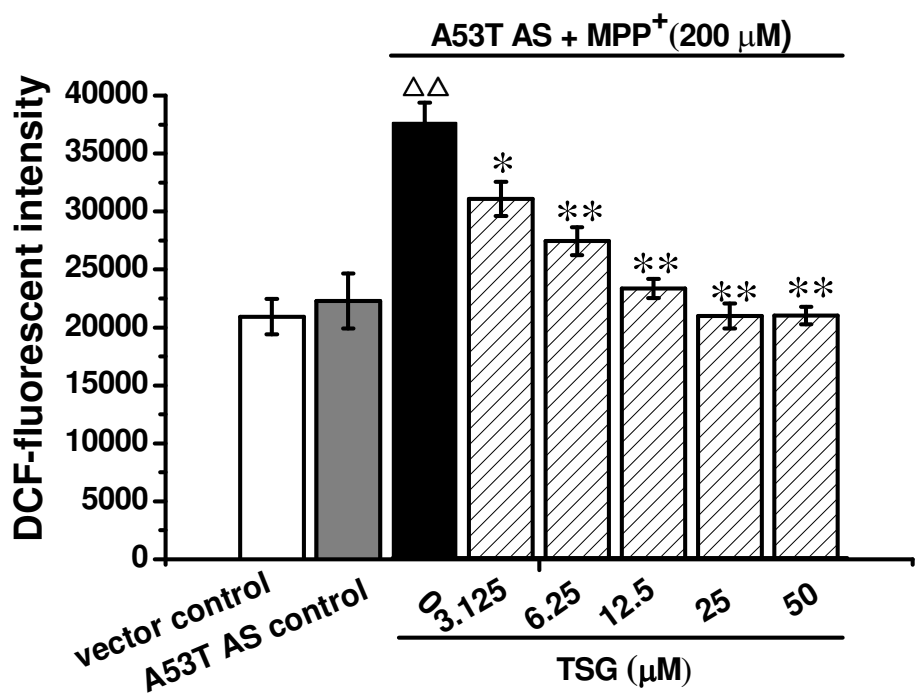


Fig.7
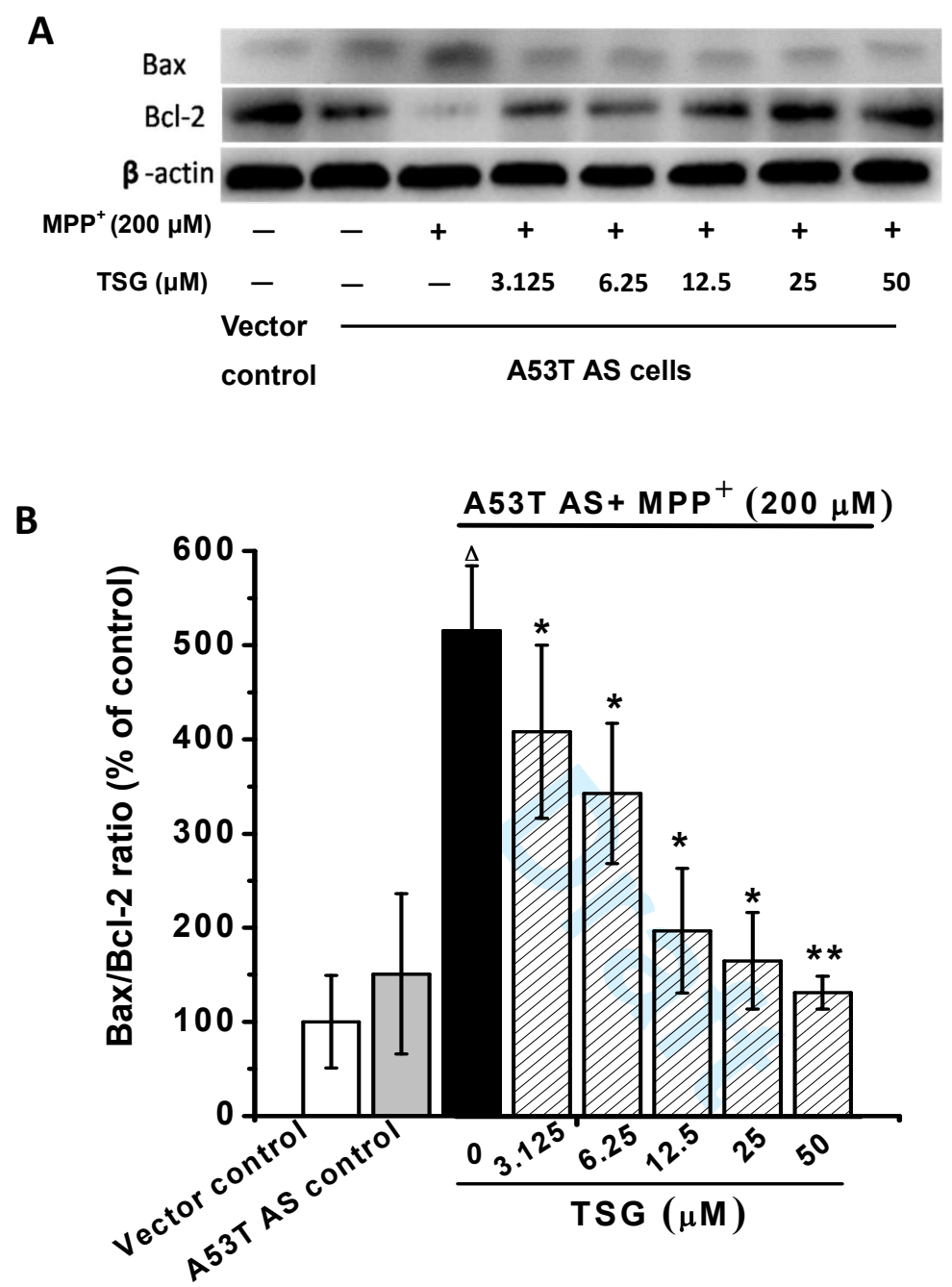
Fig.8

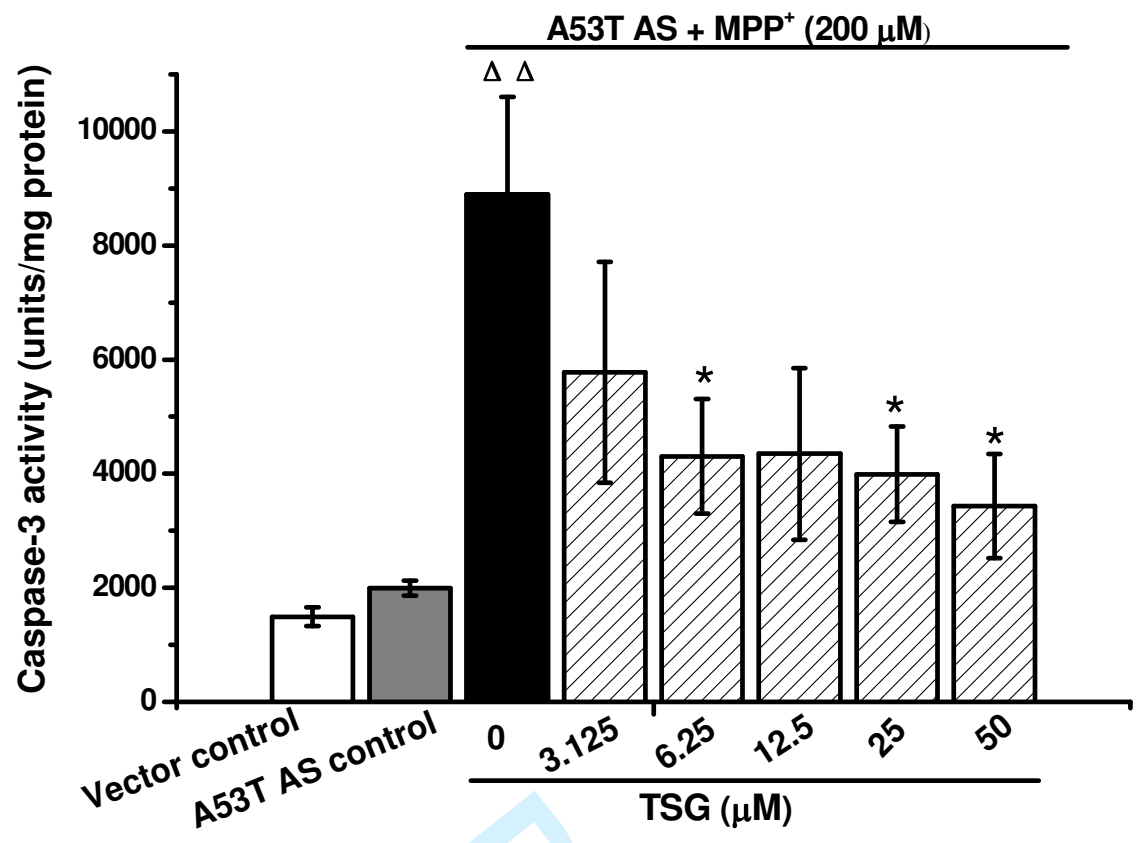


Fig.9

A
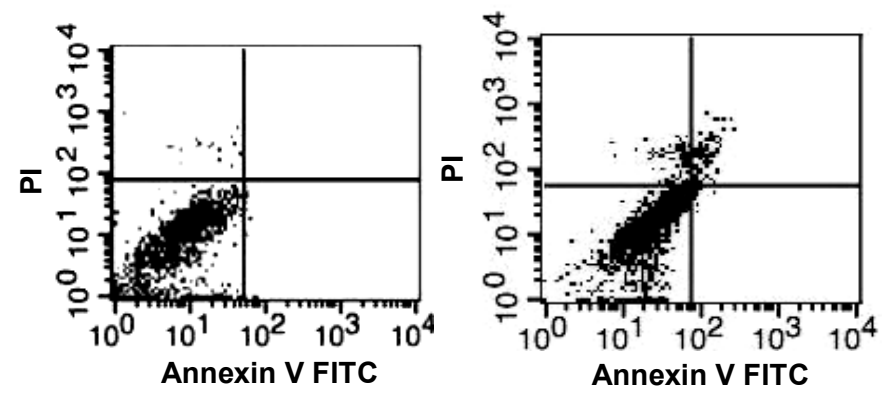

Vector control

A53T AS control cells
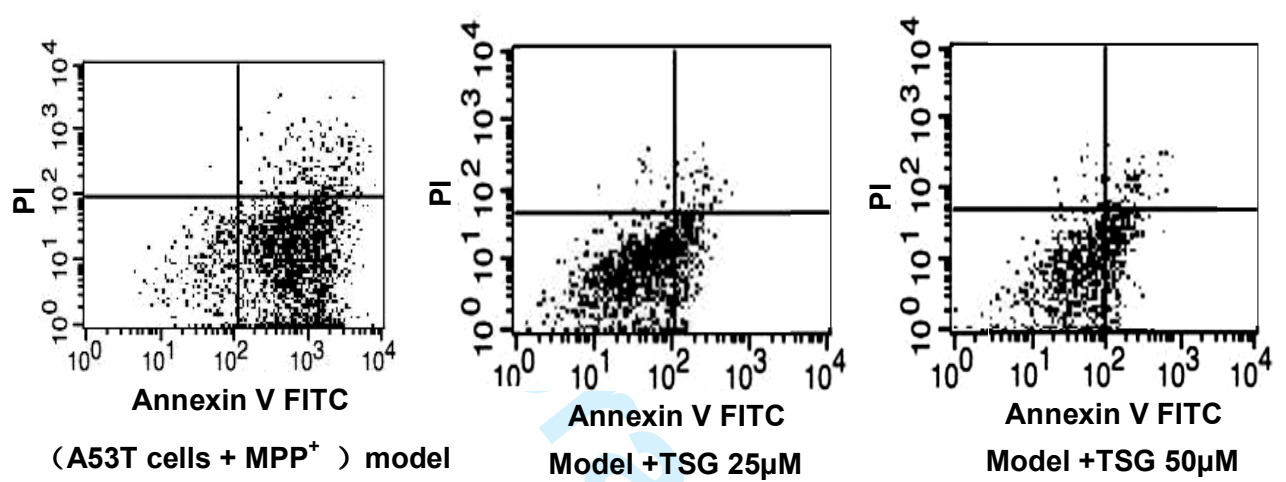

B

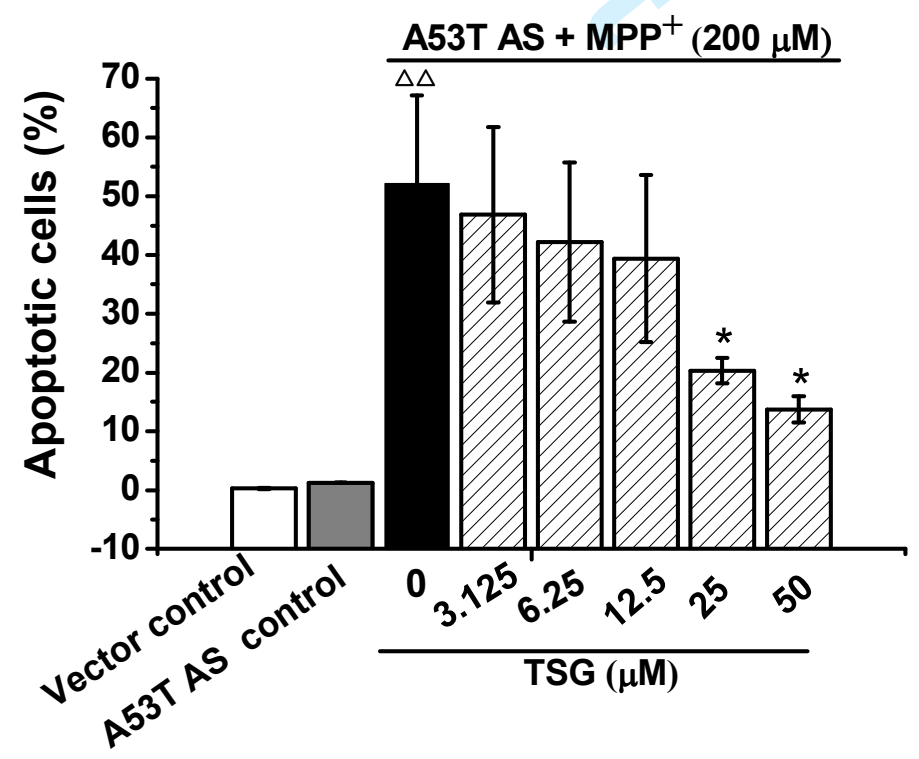

